\title{
Diálogo entre la filosofía del derecho tomista y la filosofía del derecho contemporáneo
}

Línea de investigación: Pensamiento Ético Político de Santo Tomás y Tradición Dominica

Director de la investigación: Profesor Carlos Alberto Cárdenas Sierra

\section{JUSTIFICACIÓN}

Llamamos ética aquella zona de la vida humana que está dominada por el sentido del deber. La ética no equivale a la moral. Su función es reflexionar críticamente sobre las distintas formas de deber: deber moral, deber religioso, deber jurídico, deber político, deber económico. Así concebía Tomás de Aquino el papel de la ética, a la que denominaba "filosofía moral" y que abarcaba los sectores normativos señalados. Hoy, como en el siglo XIII, retorna una preocupación semejante: de nuevo reclamamos la intervención de la ética como veedora y reguladora de los distintos órdenes normativos, especialmente del orden normativo jurídico. El afán por separar ética y derecho parece preocupación superada. Los nuevos jusfilósofos construyen un metalenguaje ético que se ordena a comprender el derecho positivo a la luz de una determinada opción antropológica y axiológica y a establecer su dependencia del devenir social, definiendo sus relaciones con la moral, la religión, la política y la economía. 




El esquema anterior muestra que Ilamamos ética a aquella zona de la vida humana que está dominada por el sentido del deber ser (porque hay formas de "deber ser" arracionales o irracionales). Dentro de esta zona distinguimos cinco reinos por lo menos, cinco formas racionales de vida ética. La ética se constituye en un saber sobre el "deber ser", que acoge como objeto propio la reflexión sobre el deber ser" de esos cinco órdenes normativos; es ella la que define el estatuto de uno u otro: primacía de la dimensión interna de la acción religiosa y moral, primacía de la dimensión externa de la acción jurídica, política y económica; autonomía relativa de los cinco órdenes normativos e intersecciones o cruces históricos más frecuentes; mayor extensión de los ámbitos religioso y moral, pues su competencia abarca todo acto humano en sus dos dimensiones, mientras el derecho se especializa en un sector de las acciones intersubjetivas quedando excluida siempre la actividad puramente interna.
El purismo formalista, puramente deontologista, que pretende someter la realidad social al "lecho de Procusto" normativo, es cada vez más superado por la conciencia de que hay que atender a los valores colectivos, a las expectativas sociales, en una postura prioritariamente consecuencialista. Solamente así se legitiman las instituciones jurídicas y políticas. ¿Qué demanda la vida social y qué valores de coexistencia están en juego?, eso es lo que preocupa más al jusfilósofo contemporáneo.

Puesto que la jusfilosofía tomista traducía análogas inquietudes dentro de su contexto socio-político, sacudido por no pocos conflictos y cambios renovadores, parece que volver a leer y a interpretar los textos tomistas desde nuestra circunstancia contemporánea puede ayudar a enriquecer los debates jusfilosóficos actuales. Por otra parte, la Facultad de Derecho de la Universidad Santo Tomás, inspirada por el pensamiento "humanista cristiano" del Aquinate, debe ser 
coherente con lo que tal humanismo implica de fidelidad a la historia cristiano-tomista, a nuestra propia historia colombiana, y a la vocación de "perennidad" de esta filosofía. Desde sus orígenes, el filosofar tomasiano pretendía funcionar en tres sentidos: eslabón con el gran pasado, luz para el presente y doctrina universal para todos los tiempos. Los tomasinos debemos verificar el alcance de un pensamiento institucionalmente vigente.

Todo lo anterior justifica el título del presente proyecto de investigación: “Diálogo entre la filosofía del derecho tomista y la filosofía del derecho contemporáneo", con la intención de alcanzar un nivel de diálogo que posibilite el encuentro constructivo entre distintas maneras de filosofar sobre el derecho, tanto desde el punto de vista del quid ius del filósofo profesional como del quid iuris de los profesionales del derecho.

La hipótesis acerca de los resultados del diálogo es que la jusfilosofía tomista resulta tan abierta e incluyente que, sin renegar de sus presupuestos, puede ayudar a construir un nivel jusfilosófico integrador que permita articular todos los aportes compatibles. La tarea integradora se vuelve esencial cuando la demanda social, por naturaleza compleja, no resiste reduccionismos.

\section{EL PROBLEMA}

\subsection{Ubicación del problema}

El derecho es inseparable de la existencia social del hombre. Señala el paso de las sociedades animales a las sociedades humanas. En toda fase de la organización social ha existido un mínimo de protección y limitación de la convivencia y del arbitrio individual mediante pautas reguladoras de la intersubjetividad: en el clan o gens, a través de pautas consuetudinarias respaldadas por la solidaridad cuasi-orgánica del grupo; en las «sociedades políticas» de poder individualizado más avanzadas (polis griega, imperio romano), por reglas interpretadas y aplicadas por tribunales y magistraturas; en las "sociedades políticas" de poder institucionalizado (Estado moderno y contemporáneo), especialmente mediante leyes escritas, textos constitucionales y operadores de creación, aplicación y control.

Desde antiguo, ha habido preocupación por establecer la noción del derecho, su fundamentación, su método y sus relaciones con los demás órdenes normativos, objeto de la reflexión ética. Tomás de Aquino recoge la cuádruple preocupación tanto de la tradición griega como de la romana y la judeo-cristiana, sin descartar las tradiciones judeo-musulmanas.

Se trata, en esta investigación, de contrastar las soluciones tomistas a los cuatro problemas con las soluciones de las más influyentes corrientes jusfilosóficas contemporáneas.

2.1.1 Estado del arte. En los últimos años de la década de los 80 y los primeros cinco años de la década de los 90, la Facultad de Derecho de la USTA quiso contribuir a la filosofía y ciencia del derecho nacionales con obras que presentaban un enfoque original del derecho, con intención de hacer aportes para el ius condendum. Entre 1988 y 1991, con autoría del Decano de la División de Filosofía-Derecho de entonces, Padre Joaquín Zabalza Iriarte, O.P., se publicaron El derecho, Tomás de Aquino y Latinoamérica y EI derecho objetivo del 25\%. Durante la década del 80, la reflexión sobre el derecho se tradujo en ponencias para uno de los Congresos Internacionales de Filosofía Latinoamericana y en artículos para varios números de las revistas Cuadernos de filosofía latinoamericana, Módulos e IUSTA.

Durante las décadas del 80 y del 90 hubo preocupación entre docentes de la División Filosofía y Derecho por adelantar investigaciones acerca del rendimiento de la jusfilosofía tomista frente 
a los nuevos enfoques jusfilosóficos. Hasta qué punto la jusfilosofía tomista podría recuperar vigencia en relación con las grandes inquietudes de la comunidad investigativa jusfilosófica internacional, latinoamericana y colombiana: ese era el problema central que motivaba a los potenciales investigadores, que debieron aplazar por años la concreción de un proyecto.

El actual proyecto de investigación en torno a los cuatro problemas de la filosofía del derecho (noción, fundamento, método, derecho en la vida ética) en perspectiva tomista recoge esa antigua preocupación de la Facultad y la División, y se propone continuar la tarea reflexiva y crítica iniciada en las obras mencionadas, buscando siempre la renovación del pensamiento tomista mediante la apertura dialogal a otros enfoques. Esta era precisamente la actitud de Tomás de Aquino al construir su discurso filosófico y teológico, sin escrúpulos de cara al pensamiento de los no cristianos.

Desde hace más de 30 años, la USTA, a través de la Facultad de Filosofía y su Maestría en Filosofía Latinoamericana, viene investigando la recepción de las corrientes filosóficas en Colombia y América Latina. Al mismo tiempo, ha venido recuperando las fuentes documentales para hacer una historia de la filosofía de estos países y de la gran patria continental. Dentro de esa preocupación investigativa, siempre estuvo presente la intención de indagar por la filosofía ética, política y jurídica, preguntándose cómo se recepcionaron las corrientes foráneas de prestigio internacional y qué se produjo en estos países de periferia económico-política, bien por transformación adaptativa, como mera reproducción o como réplica creativa.

2.1.2 Planteamiento del problema. Podemos plantearnos el problema que motiva la presente investigación de esta manera: ¿cuáles son los paradigmas jusfilosóficos tomistas y cuál es su alcance ante los reclamos de la realidad social, política y económica contemporánea, en contraste con los paradigmas de las jusfilosofías contemporáneas más influyentes?

\section{IMPACTO ESPERADO}

\section{1 Ámbitos de impacto}

- División de Filosofía-Derecho.

- Ámbito USTA.

- Ámbito académico nacional.

- Ámbito social.

- Otros por determinar.

\subsection{Impacto en usuarios}

Las personas y organismos que se podrían beneficiar de esta investigación son, en su orden:

- Los estudiantes, profesores y directivos de la División de Filosofía-Derecho USTA.

- Los estudiantes, profesores y directivos de Facultades de Derecho y ciencias sociales.

- Los centros de investigación jurídica y social.

- Las entidades gubernamentales encargadas de los problemas jurídico-sociales.

- Entidades no gubernamentales.

- Otros por determinar.

\section{OBJETIVO GENERAL}

Continuar la tradición investigativa jusfilosófica de la División de Filosofía y Derecho de la USTA, reconstruyendo el paradigma jusfilosófico tomista en diálogo con los paradigmas jusfilosóficos contemporáneos, de cara a las exigencias de la convivencia y la coexistencia colombianas, en contexto latinoamericano y mundial. 


\subsection{Objetivos específicos}

- Recopilar, interpretar y analizar las fuentes primarias y secundarias de la jusfilosofía tomista para definir sus propios paradigmas.

- Recopilar, interpretary analizar las obras más influyentes de la jusfilosofía contemporánea para definir sus paradigmas.

- Contrastar los paradigmas tomistas con los paradigmas jusfilosóficos contemporáneos escogidos, desde la perspectiva de las exigencias de la vida contemporánea.

- Difundir periódicamente los resultados de la investigación

\subsection{Marco teórico}

El amplio campo de la filosofía del derecho, de la política y de la economía proporciona varios marcos teóricos conexos, es decir, conjuntos sistemáticos de teorías comprensivo-explicativas de los distintos problemas que han sido objeto de investigación en los tres ámbitos señalados. Las teorías jusfilosóficas no han excluído los ámbitos político y económico ni las filosofías política o económica han hecho caso omiso del aspecto jurídico. Si bien hemos establecido tres líneas especializadas, el marco teórico jusfilosófico tendrá en cuenta las relaciones entre fenómeno jurídico y fenómenos político y económico. La misma jusfilosofía tomista, al establecer la noción del derecho ya supone su alcance económico y sus implicaciones en la vida política. De manera semejante, han enfocado el fenómeno jurídico las escuelas más sobresalientes.

El marco teórico iluminador del esfuerzo de comprensión y de contraste de la jusfilosofía tomista con las corrientes jusfilosóficas contemporáneas es la síntesis de las sucesivas formas de comprender el mundo jurídico a lo largo de la histo- ria de la reflexión jusfilosófica occidental, a partir de los primeros escarceos presocráticos hasta las definiciones de la Academia y el Liceo, llegando a los pensadores estoicos, que van a influir muy directamente en el pensamiento jusfilosófico de los teólogos cristianos, abiertos más tarde a las influencias judeo-musulmanas.

Tomás de Aquino, quien no ve en primer lugar el aspecto normativo del derecho, sino su concreción en "la cosa" (res iusta) debida a otro, de acuerdo con las demandas de las tendencias naturales que guían el ejercicio de la razón práctica, será heredero de todas esas tradiciones y se convertirá en uno de los más autorizados maestros del jusnaturalismo cristiano, con influjo desigual en la Iglesia Católica durante los últimos 700 años, especialmente en la construcción de la doctrina social de la Iglesia, y con algún influjo en otras tradiciones.

Tomás de Aquino, sin embargo, no representa solamente la tradición jusnaturalista, pues su definición de la ley (mensura iuris) integra tanto las exigencias del derecho natural y de los valores de coexistencia como las exigencias del derecho positivo, condicionado por los requerimientos de la vida social (cura communitatis). De esa manera, el paradigma integralista tomista parece apto para dialogar con todas las doctrinas jusfilosóficas que fueron construyéndose desde la Edad Media hasta hoy, y que se han alternado enfatizando ya la opción jusnaturalista, ya la opción historicista, ya la opción sociologista, ya la opción positivista o bien la opción finalista, de tal manera que, actualmente, se oscila entre uno y otro extremo o se prefieren constructores mixtos.

De acuerdo con los maestros más reconocidos de la jusfilosofía tomista, el esfuerzo por comprender cabalmente esta forma de pensar sobre el derecho debe tener en cuenta los siguientes aspectos: 
- Realismo jurídico tomista.

- La ley en el realismo jurídico.

- Derecho y justicia.

- Ley natural y ley positiva.

- El fin del derecho (orden, paz, bien común).

- Persona y sociedad.

- Derecho y régimen político.

- Derecho y vida ética.

- Derecho y ius gentium.

Para profundizar la originalidad de las posturas tomistas, estos aspectos serán contrastados con los paradigmas de cada gran marco doctrinal, de acuerdo con la sucesión de escuelas señalada. Para el diálogo actual, se tendrán en cuenta especialmente los siguientes debates:

- Los debates contemporáneos

- Tercera vía y principio de tolerancia (Radbruch y Kaufmann).

- Lógica jurídica y teoría de la argumentación (Perelman).

- Positivismo suave vs. naturalismo (Hart-Dworkin).
- Neocontractualismo y principio de equidad (Rawls).

- Facticidad, validez y argumentación (Habermas y Alexy).

- Critical Legal Studies (Trubek y Kennedy).

- Law and society.

\section{- Los debates colombianos}

- Relaciones centro-periferia.

- Centros de producción teórica y centros de recepción.

- Formas de recepción de la jusfilosofía en Colombia.

- Positivismo exegético.

- Sociologismo y finalismo.

- Positivismo kelseniano.

- Deontologismo vs. consecuencialismo.

- Antiformalismo. 